\title{
Deposition of platinum group elements and polycyclic aromatic hydrocarbons on ryegrass exposed to vehicular traffic
}

\author{
Abdourahamane TANKARI DAN-BADJo, Cécile Ducoulombier-CréPINEAU*, Claire Soligot, Cyril FeIDT, \\ Guido RYCHEN
}

UR AFPA-ENSAIA-INPL-INRA, 2 avenue de forêt de la Haye, 54505 Vandœuvre-Lès-Nancy, France

(Accepted 15 March 2007)

\begin{abstract}
Along highways, platinum group elements (PGE: Pt, Pd and Rh) and polycyclic aromatic hydrocarbons (PAHs) produced by the vehicle traffic can be deposited on grass and soil, leading to a risk of contamination through the food chain via farm animals. We studied the deposition of platinum group elements and polycyclic aromatic hydrocarbons on ryegrass pots exposed along a highway with 65000 vehicles per day for 90 days in summer and autumn. After this exposure period, the ryegrass pots were transferred to a remote area for 5 weeks. The Pt, $\mathrm{Pd}$ and $\mathrm{Rh}$ concentrations were determined in ryegrass samples using inductively coupled plasma mass spectrometry (ICP-MS) and PAHs were quantified by high-pressure liquid chromatography (HPLC). Our results show that Pd and Rh concentrations increased with time of exposure. Pd concentrations ranged from 1.5 to $6.8 \mathrm{ng} / \mathrm{g}$ dry weight (d.w.), Rh from 1.5 to $3 \mathrm{ng} / \mathrm{g}$ d.w. and Pt from 0.3 to $1.4 \mathrm{ng} / \mathrm{g}$ d.w. The total PAH concentrations varied from 6 to $175 \mathrm{ng} / \mathrm{g}$ d.w. PGE and PAH deposition on ryegrass near the highway occurred mainly for the first weeks of exposure. During the 5 weeks following the exposure, the levels and profiles of PAHs and PGE (except Rh) in highway grasses transferred to a remote area did not significantly decrease, suggesting a potential risk of contamination for dairy ruminants.
\end{abstract}

Pt / Pd / Rh / PAHs / ryegrass / deposition / vehicular traffic

\section{INTRODUCTION}

Road traffic is responsible for metallic and organic pollutant emissions that are likely to contaminate the environmental matrices (Colvile et al., 2001). Among these pollutants, this study focused on platinum group elements and polycyclic aromatic hydrocarbons. Platinum group elements are produced from the abrasion of the automotive catalyst washcoat. Platinum (Pt), palladium $(\mathrm{Pd})$ and rhodium $(\mathrm{Rh})$ are used as catalysts to convert toxic gases (carbon monoxide, hydrocarbons and oxides of nitrogen) into water, carbon dioxide and nitrogen (Barefoot, 1999). Several authors have observed a link between the increase in catalyst used in the vehicle industry and the increase in platinum group element concentrations in the environment (Barbante et al., 2001; Djingova et al., 2003). Moreover, Pt concentrations ranging from 1.2 to $30 \mathrm{ng} / \mathrm{g}$ have been detected in grass samples collected in the vicinity of highways (Ely et al., 2001; Djingova et al., 2003), whereas the Pt concentration in grass collected far away from all contamination sources was lower than $0.03 \mathrm{ng} / \mathrm{g}$ dry weight (Helmers and Mergel, 1998). Studies have demonstrated that plants are able to assimilate Pt, Pd and Rh (Pallas and Jones, 1978; Schäfer et al., 1998). Some platinum compounds are known to be cytotoxic and may have mutagenic and carcinogenic effects (Gebel et al., 1997). Pd and its compounds are known to be potentially allergenic (Castelain and Castelain, 1987). Pd and Rh are known to

* Corresponding author:

Cecile.ducoulombier-crepineau@ensaia.inpl-nancy.fr be less cytotoxic than Pt ( 2 times and 30 times, respectively) and have a smaller mutagenic potential (Bunger et al., 1996).

PAHs are produced by incomplete combustion of organic matter at high temperatures (Shabad et al., 1980). Road traffic is one of the main PAH emission sources (Hautela et al., 1995; Duran et al., 2001). Several studies have detected total PAH concentrations ranging from 120 to $950 \mathrm{ng} / \mathrm{g}$ in grass samples collected in the vicinity of roads and highways (Bryselbout et al., 2000; Crépineau-Ducoulombier et al., 2003). PAHs are potentially mutagenic and persistent compounds in the environment (Shabad et al., 1980). PGE and PAH emissions due to road traffic represent a potential source of fodder contamination. These compounds may enter into the food chain by massive ingestion of contaminated fodder by dairy ruminants. Indeed, PGE (Crépineau-Ducoulombier et al., 2005) and PAHs (Grova et al., 2000, 2006) may be detected in milk after oral administration of these compounds. The objective of this study is to determine $\mathrm{Pt}, \mathrm{Pd}, \mathrm{Rh}$ and $\mathrm{PAH}$ deposition on fodder (ryegrass). Ryegrass pots were exposed along a highway to determine the effects of the exposure duration and the evolution of the pollutant concentrations in the plants after removal from the highway.

\section{MATERIALS AND METHODS}

\subsection{Cultivation of ryegrass plants}

To limit the variability of in situ sampling, we used and adapted the biomonitoring method (German VDI 3957) 
based on the monocotyledon Lolium perenne (Garrec and Van Haluwyn, 2002) which is currently used to assess organic (Crépineau-Ducoulombier et al., 2004) and metallic (Klumpp et al., 2002) contaminations in fodder. Furthermore, ryegrass is a fodder widely used in ruminant rations. In a climate chamber maintained under standardized conditions of temperature $\left(15^{\circ} \mathrm{C}\right)$, luminosity ( $14 \mathrm{~h}$-day/10 h-night) and humidity (60 to $80 \%$ ), the ryegrass was cultivated in ninety-one pots of 22.5 $\mathrm{cm}$ in diameter. Each pot was filled with $5 \mathrm{~kg}$ of soil (Castorama, NF U 44-571, 23\% organic matter), seeded with 1.35 $\mathrm{g}$ of seeds $\left(34 \mathrm{~g} / \mathrm{m}^{2}\right)$ and watered with $250 \mathrm{~mL}$ of tap water three times a week directly on the soil to avoid any washing off of the grass. One month after seeding, the ryegrass was cut every five days with washed scissors, $8 \mathrm{~cm}$ from the soil to stimulate growth. When exposed, the pots were put at ground level to simulate grass in pastures. The ryegrass was $25 \mathrm{~cm}$ above the bottom; this was enough to avoid splashes of local soil. Moreover, to avoid any contact with local grass, all vegetation had been previously removed around the pots and was regularly cut during the experiments. Pt, Pd and Rh concentrations in the soil were determined because platinum group element transfer from the soil toward the plant has previously been suspected (Schäfer et al., 1998). The concentrations were $0.25,2.1$ and $18.3 \mathrm{ng} / \mathrm{g}$ dry weight, respectively, for Pt, $\mathrm{Rh}$ and $\mathrm{Pd}$, which are usual concentrations in soil. For PAHs, soil concentrations were not established because PAH transfer from soil toward the plant is known to be negligible (Wild et al., 1992; Kipopoulou et al., 1999).

\subsection{Sampling sites}

Two sites were chosen in the same area, "the Plateau Lorrain" (East of France), and were less than $20 \mathrm{~km}$ apart: a road site (highway A33) where the daily average traffic was 65000 vehicles and a remote site: a pasture at the experimental farm of the laboratory (Bouzule) located $700 \mathrm{~m}$ from the nearest road.

\subsection{Exposure of ryegrass pots on sites}

After 4 weeks of cultivation under controlled conditions in a climate chamber, the 84 pots of ryegrass were placed randomly at a distance of $5 \mathrm{~m}$ from the verge of the highway A33 on the side of the prevailing wind for 90 days. 7 Pots were not exposed and were used as control and placed in a greenhouse. The sampling frequency was every 15 days (grass was collected from 7 pots). After the 90th day of exposure, the 35 remaining pots of ryegrass were transferred to the remote site (Bouzule) for a further period of 5 weeks (week 1 to week 5). The sampling was then carried out every week (7 pots each week). The grass samples were cut with washed scissors (using distilled water, acetone and hexane) $6 \mathrm{~cm}$ from the soil in order to avoid all telluric interference and were immediately wrapped in aluminium paper. Pt, Pd, Rh and PAH concentrations were determined in all exposed ryegrass samples as well as in the control pots of ryegrass.

\section{4. $\mathrm{Pt}, \mathrm{Pd}, \mathrm{Rh}$ and $\mathrm{PAH}$ analysis in ryegrass}

Grass samples were dried for 5 days at $30{ }^{\circ} \mathrm{C}$, in a climate chamber, and ground (Retsch grinding) using a $1.5-\mathrm{mm}$ sieve.

$\mathbf{P t}, \mathbf{P d}$ and Rh extraction and analysis. The extraction and analysis of platinum group elements was performed by the "Laboratoire des Pyrénées" (Lagor, France) using the norm NF EN ISO 17294-2. The dried grass samples were mineralized using a Thermo Electron ETHOS 1600 microwave. $1 \mathrm{~g}$ was placed in the digestion container. $2.5 \mathrm{~mL}$ of nitric acid $69 \%, 1 \mathrm{~mL}$ of oxygenated water $30 \%$ and $5 \mathrm{~mL}$ of deionized water were added. After agitation, the mixture was left to rest for about 12 hours. After launching of the digestion program, a progressive rise in temperature up to $160^{\circ} \mathrm{C}$ was applied to obtain a landing of mineralization. This landing was maintained for 15 minutes. At the end of the digestion, the mineralized matter was placed in a vial.

Analysis of platinum group elements was done by inductively coupled plasma mass spectrometry (ICP/MS) using a VARIAN 810 UltraMass using internal standards: Iridium 194 for Pt (194-195), and Inadium 115 for Pd (106-108) and for $\mathrm{Rh}$ (104-105). The evaluation of the method was carried out following the norm XPT 90-210. For the precision of the analysis, five standard curves were used, validated by a Fisher test. Quantification limits are $0.25 \mathrm{ng} / \mathrm{g}$ dry weight for $\mathrm{Pt}$ and $\mathrm{Rh}$, and $0.5 \mathrm{ng} / \mathrm{g}$ dry weight for Pd.

PAH extraction and analysis. PAH extraction and analysis was performed at UR AFPA-INPL (Nancy, France). PAH extraction was carried out on dried grass using the procedure described by Dugay et al. (2002). Two grams of grass were mixed with $50 \mathrm{~mL}$ toluene and placed in an ultrasound bath (SM35E-DTH, Bransonic) for 2 hours. After filtration (Cat No 1820150, Whatman), the solution was evaporated to dryness at $40{ }^{\circ} \mathrm{C}$, and the residue saponified for $30 \mathrm{~min}$ at $60^{\circ} \mathrm{C}$ with $50 \mathrm{~mL}$ of an $80 \%(\mathrm{v} / \mathrm{v})$ methanol-water solution containing $1 \mathrm{M} \mathrm{KOH}$. The saponified solution was cleaned up by solidphase extraction using OASIS HLB cartridges. After the solution was deposited, the cartridges were washed with $10 \mathrm{~mL}$ of water and the PAHs were eluted with $8 \mathrm{~mL}$ of methylene chloride. The extract containing PAHs was dried with anhydrous $\mathrm{Na} 2 \mathrm{SO} 4$ and evaporated to dryness under nitrogen using a dry bath (DB 3 Techne), and the residue was dissolved in $1 \mathrm{~mL}$ acetonitrile. The solution was stored overnight at $-20^{\circ} \mathrm{C}$, before HPLC analysis.

The HPLC system included a controller (Waters 600), an autosampler (Waters 717 plus) equipped with a $20-\mu \mathrm{L}$ injection loop, a column oven (600 treater), a fluorescence detector (Waters 2475) and data-processing software (Millennium 32). HPLC analysis was carried out using a Vydac 201 TP 54 column $(250 \times 4.6 \mathrm{~mm}$ ID, particle size $5 \mu \mathrm{m})$ with a gradient elution program using $\mathrm{H}_{2} \mathrm{O}$ and $\mathrm{CH}_{3} \mathrm{CN}$. Detection was performed by fluorimetry. All solvents were analytical- or HPLCgrade reagents. The $\mathrm{KOH}$ and anhydrous $\mathrm{Na}_{2} \mathrm{SO}_{4}$ were p.a. grade. Glassware was baked out at $500{ }^{\circ} \mathrm{C}$ or solvent rinsed with toluene prior to use. The PAH 610 polynuclear aromatic hydrocarbons mix was obtained from Interchim (M-610-QC).

The mobile phase comprised acetonitrile (A) and ultrapure water (B). Gradient elution conditions were as 
follows: 0-20 min, linear gradient 40\% A-80\% A; 20-30 min, $80 \%$ A isocratic; 30-40 min, linear gradient $80 \%$ A-95\% A; 40-50 min, 95\% A isocratic. The flow rate was $1 \mathrm{~mL} . \mathrm{min}^{-1}$. The excitation and emission wavelength program for PAH detection varied, respectively, from 250 to $295 \mathrm{~nm}$ and from 355 to $420 \mathrm{~nm}$. PAH calibration curves were performed by diluting a standard mixture (M-610-QC, Interchim) containing the 16 PAHs of the United States Environmental Protection Agency (US-EPA). The extraction yield varied from 35 to $111 \%$ according to the PAH. The final result was expressed in $\mathrm{ng} / \mathrm{g}$ dry weight and the quantification limit was $0.5 \mathrm{ng} / \mathrm{g}$ dry weight.

\subsection{Statistical analysis}

Analysis of variance using the SAS statistical software General Linear Model (GLM) procedure was applied to the PGE and PAH concentrations at the various exposure times at a significance level of 5\%. Data is presented as mean and standard deviation.

\section{RESULTS AND DISCUSSION}

\subsection{Platinum group element deposition on ryegrass}

Figure 1 shows the $\mathrm{Pt}, \mathrm{Pd}$ and $\mathrm{Rh}$ concentration evolution in the ryegrass during the exposure to the highway, from day 0 to day 90, and after the removal of the pots and placement in the remote pasture, from week 1 to week 5 . The exposure of the ryegrass pots to the highway led to an increase in all studied compounds. Pd and Rh concentrations were found to increase significantly with time of exposure. Pd concentrations were also higher than those of $\mathrm{Rh}$ and $\mathrm{Pt}$. $\mathrm{Pd}$ concentrations ranged from 1.5 to $6.8 \mathrm{ng} / \mathrm{g}$ dry weight while $\mathrm{Rh}$ concentrations were found between 1.6 and $3 \mathrm{ng} / \mathrm{g}$ dry weight and Pt concentrations ranged from 0.3 to $1.4 \mathrm{ng} / \mathrm{g}$ dry weight.

The concentrations of Pd and Pt shown in Figure 1a, c suggest a two-step deposition process. During a first step from day 0 to day $8, \mathrm{Pd}$ and $\mathrm{Pt}$ concentrations increased rapidly by a factor of 3; then during a second step from day 8 to day 90 , concentrations varied by a factor lower than 2 . For the Rh concentrations shown in Figure $1 \mathrm{~b}$ the variation factor between the exposed and unexposed ryegrass was low $(<2)$. Figures 1a, c also indicate an absence of decrease in Pd and Pt concentrations when the pots were placed at the remote site. For Rh, concentrations were found to be reduced when placed at the remote site (Fig. 1b). This observation suggests that these compounds are not only found on grass surfaces but probably are adsorbed in the cuticular waxes or penetrate the plant's internal tissues. Pt and Pd adhesion to plant tissue appears to be strong, although their behavior is still unknown. In order to determine the way the PGE were fixed to the plant tissues, we treated contaminated ryegrass plants with chloroform, according to Garrec and Renard (1996). After this treatment, more than $50 \%$ of PGE remained fixed to the ryegrass. This result contributes to explain why the concentrations did not decrease considerably even when the contaminated ryegrass samples were placed far away from the highway.

The platinum group element distribution was found to be different between exposed ryegrass and unexposed ryegrass. In unexposed ryegrass at day 0 the $\mathrm{Pd}$ concentration of $1.5 \mathrm{ng} / \mathrm{g} \mathrm{d}$.w., and that of Rh of $1.6 \mathrm{ng} / \mathrm{g} \mathrm{d.w}$. were similar, and higher than the Pt concentration of $0.3 \mathrm{ng} / \mathrm{g} \mathrm{d} . \mathrm{w}$. In the exposed ryegrass from day 8 to day 90, Pd concentrations increased from 4.5 to $6.8 \mathrm{ng} / \mathrm{g} \mathrm{d}$.w. These $\mathrm{Pd}$ concentrations were found to be much higher than $\mathrm{Rh}$ or $\mathrm{Pt}$ concentrations, which also increased from, respectively, 1.6 to $3.1 \mathrm{ng} / \mathrm{g} \mathrm{d}$.w. and 0.7 to $1.5 \mathrm{ng} / \mathrm{g} \mathrm{d.w}$. in the same period. Thus, platinum group element distribution changed greatly during exposure: when compared with $\mathrm{Pt}$ and $\mathrm{Rh}, \mathrm{Pd}$ turned out to be the major compound and represented about $60 \%$ at day 90 . At the remote site, from week 1 to week 5 , the $\mathrm{Pd}$ concentrations of 4 to $4.7 \mathrm{ng} / \mathrm{g}$ d.w. always remained higher than Pt concentrations ( 0.6 to $1.1 \mathrm{ng} / \mathrm{g} \mathrm{d.w.)}$ and $\mathrm{Rh}$ concentrations ( 0.7 to $1 \mathrm{ng} / \mathrm{g} \mathrm{d.w.)}$ which were both similar. These results revealed a higher accumulation of Pd than Pt or Rh. This higher Pd concentration did not follow the tendency of PGE emissions by vehicles. Indeed, some studies (Moldovan et al., 1999; Rauch et al., 2002) showed that vehicles emitted more Pt than Pd on roads. For example, emission values for a diesel vehicle were: $223 \mathrm{ng} \mathrm{Pt} / \mathrm{km}, 75.8 \mathrm{ng} \mathrm{Pd} / \mathrm{km}$ and $33.7 \mathrm{ng} \mathrm{Rh} / \mathrm{km}$ (Rauch et al., 2002). The highest Pd concentrations could be explained by the properties of the $\mathrm{Pd}$ compounds which are more soluble and more mobile in the environment than $\mathrm{Pt}$ and $\mathrm{Rh}$ compounds (Moldovan et al., 2001) and therefore more bioavailable for plants.

The results of platinum group element analysis also showed a non-negligible concentration of $\mathrm{Pt}, \mathrm{Pd}$ and $\mathrm{Rh}$ in unexposed ryegrass, suggesting plant contamination by soil. Platinum group element transfer from soil towards the plant was previously observed by Schäfer et al. (1998) on various plants (spinach, cress, phacelia and stinging nettle). When applying the platinum group element soil to plant transfer coefficient suggested by Schäfer et al. (1998), we concluded that this transfer seems to be negligible in our study.

\subsection{PAH deposition on ryegrass}

The total PAH concentrations varied from $6 \mathrm{ng} / \mathrm{g} \mathrm{d.w}$. at day 0 to $175 \mathrm{ng} / \mathrm{g} \mathrm{d.w}$. at day 90 (Fig. 2). Two phases could be distinguished: a first phase corresponding to the first two weeks of exposure with concentrations increasing significantly by a factor of 23; and a second phase from day 15 to day 90 with the concentrations remaining similar. This result suggests that ryegrass behaves like a bioaccumulator species. Indeed, when ryegrass is exposed to a pollutant, the concentration increases until the air - plant equilibrium is reached (Bakker et al., 2001a; Thomas et al., 1998). For ryegrass (Lolium perenne), this study indicates that in in situ conditions the airplant equilibrium seems to be reached after 15 days of exposure for PAHs. We know the time to obtain equilibrium varies according to the plant species: 24 to 240 seconds for Citrus and 58 to 580 days for Ilex (Bakker et al., 2001a). The total 

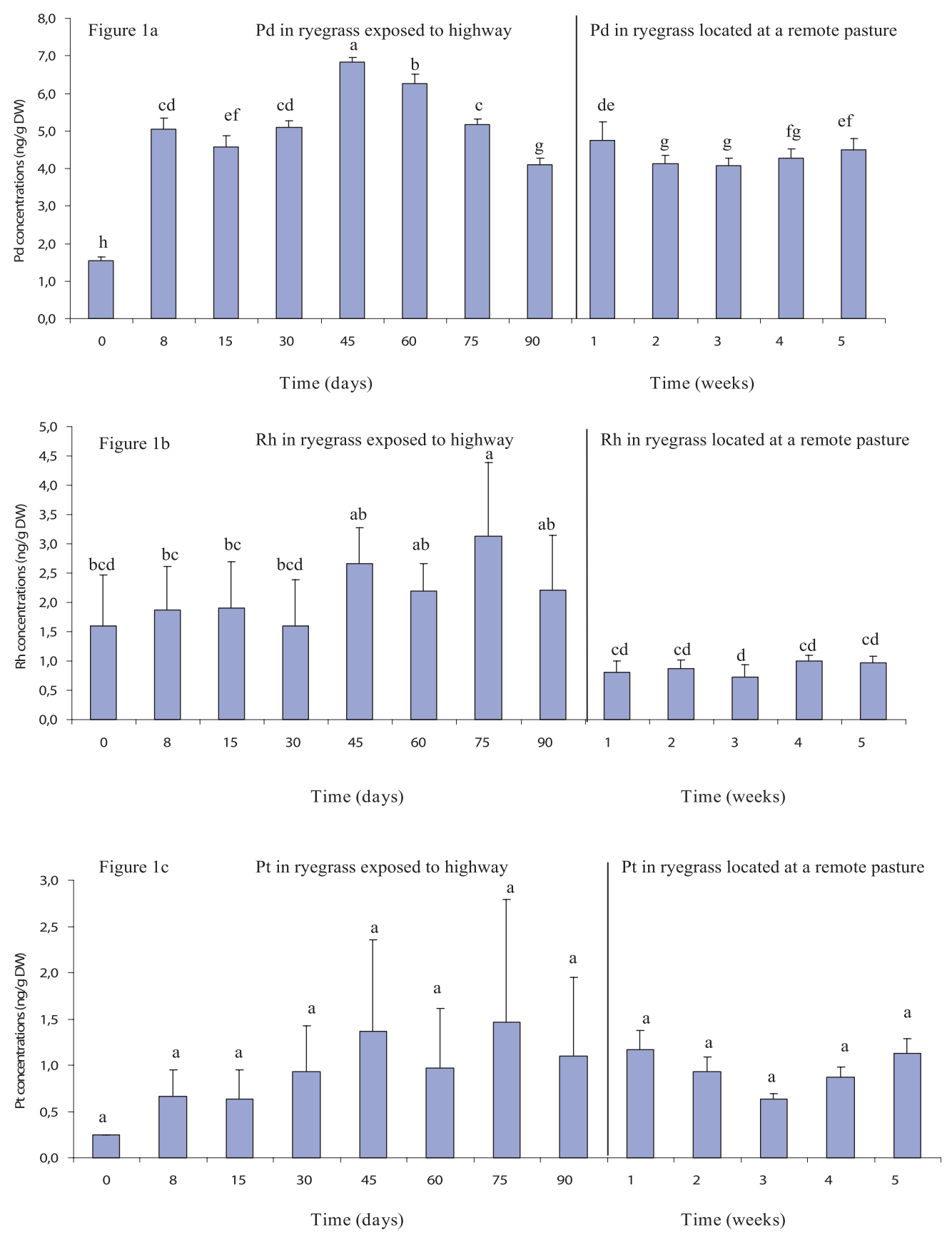

Figure 1. Pd, Rh and Pt concentration evolution in ryegrass exposed along the highway (day 0 to day 90 ) and in the remote pasture (week 1 to week 5). DW: dry weight; Pd: (a-h), Rh: (a-d), Pt: (a) for each figure, mean results without a common letter differ significantly, $P<0.05$; the vertical bars correspond to the standard deviation.

PAH concentrations at the end of the exposure period (day 90) were similar to the total PAH concentrations detected at the remote site (week 1 to week 5). This absence of decrease shows that PAHs are strongly fixed to the ryegrass. This result is in accordance with Bakker et al. (2001b), who demonstrated on two species, Plantago major and Plantago media, that PAHs are fixed in cuticular waxes and in the internal tissues of the plant leaves.
The PAH distributions shown in Figure 3 were different between the unexposed (day 0 ) and exposed ryegrass (day 8 to day 90). Only 3 compounds were detected in the unexposed ryegrass: phenanthrene, fluoranthene and pyrene, whereas 12 PAHs were detected in the exposed one. The concentrations of these 3 compounds were found to be lower in the unexposed ryegrass compared with the exposed ryegrass; because of their ubiquitous character and their strong volatility, they 


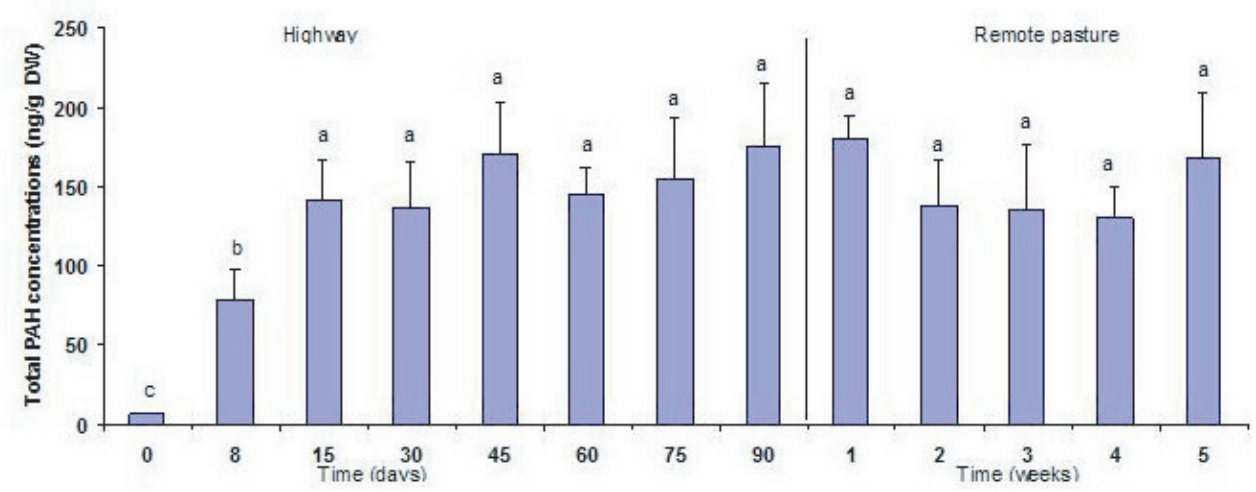

Figure 2. Total PAH concentration evolution in ryegrass exposed along the highway (day 0 to day 90 ) and in a remote pasture (week 1 to week 5). DW: dry weight; (a, b, c); mean results without a common letter differ significantly, $P<0.05$; the vertical bars correspond to the standard deviation.

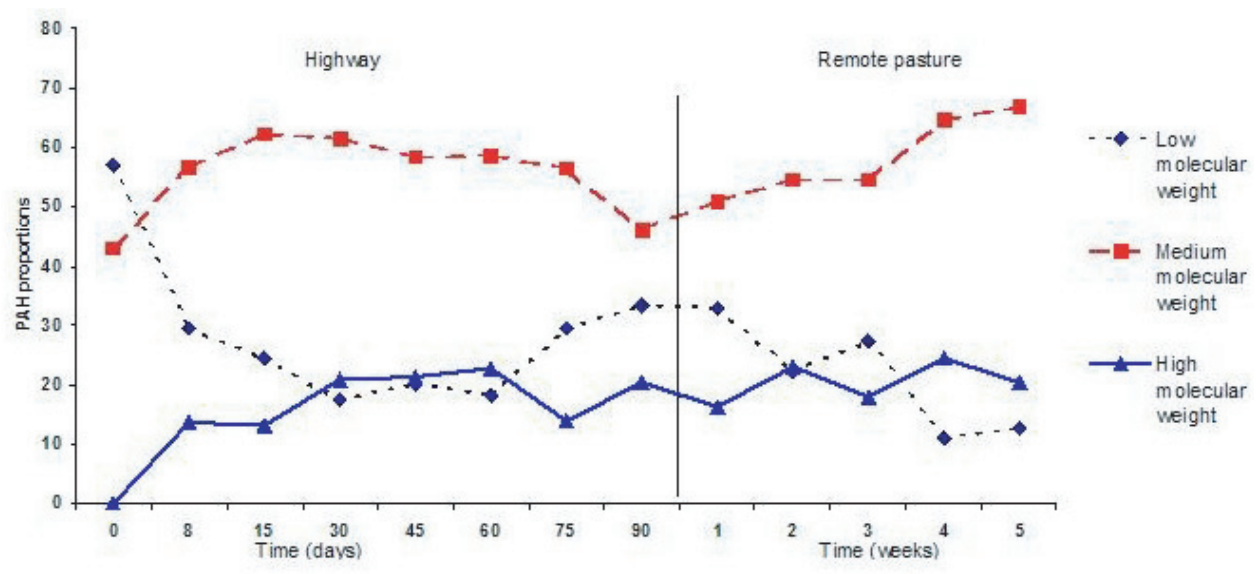

Figure 3. PAH distribution evolution in the ryegrass exposed along the highway (day 0 to day 90) and in a remote pasture (week 1 to week 5 ). Low molecular weight (PAHs of 2 to 3 rings: acenapthene, phenanthrene, anthracene); medium molecular weight (PAHs of 4 rings: fluoranthene, pyrene, benzo(a)anthracene, chrysene); high molecular weight (PAHs of 5 rings or more: benzo(b)fluoranthene, benzo(k)fluoranthene, benzo(a)pyrene, dibenzo(a,h)anthracene, benzo(g,h,i)perylene).

have even been detected in plants cultivated inside greenhouses, but their concentrations were quite low (Bakker et al., 2001b; Crépineau-Ducoulombier et al., 2004). For each time of exposure, these $3 \mathrm{PAHs}$ were the main compounds of all ryegrass samples.

Eight days after the exposure, the high molecular weight PAHs (5 and 6 rings) were detected and represented almost $23 \%$ of the total PAH concentrations (Fig. 3). For the whole exposure period (day 8 to day 90), PAH profiles were similar: 15 to $20 \%$ for high molecular weight PAHs (5 and 6 rings), 17 to $33 \%$ for low molecular PAHs (2 to 3 rings) and between 46 and $62 \%$ for intermediate PAHs (4 rings). At the remote site, the ryegrass presented the same PAH profile from the first to the fifth week. This profile was not different from the PAH profile during the exposure to the highway. The detection of high molecular weight PAHs, potentially more toxic, in exposed ryegrass at a non-negligible level demonstrates a possible contamination of fodder produced close to highways (Bryselbout et al., 2000; Crépineau-Ducoulombier et al., 2004).

\section{CONCLUSION}

Platinum group element and PAH deposition on ryegrass in the vicinity of a highway indicated that deposition mainly occurs for the first weeks of exposure to the average values of $8 \mathrm{ng} / \mathrm{g}$ for platinum group elements and $175 \mathrm{ng} / \mathrm{g}$ for PAHs. The platinum group element profile changed greatly during exposure: when compared with $\mathrm{Pt}$ and $\mathrm{Rh}$, Pd turned out to be the major compound and represented about $60 \%$ at day 90 . For PAHs, the compounds including 5 rings or more (benzo(b)fluoranthene, benzo(k)fluoranthene, benzo(a)pyrene, dibenzo(a,h)anthracene and benzo(g,h,i) perylene), and potentially more harmful, were detected only in exposed ryegrass. The absence of decrease during the 5 weeks following exposure revealed that the contaminants are strongly fixed to the ryegrass. Further investigations are necessary to characterize this fixing phenomenon better. The rapid contamination of the ryegrass during its exposure to the highway as well as the maintenance of platinum group elements and PAHs after its removal and placement in the remote pasture show the 
exposure risk of fodder cultivated near roads. Considering that the dairy ruminant does not graze exclusively near highways, we will carry out further studies to determine the $\mathrm{Pt}, \mathrm{Pd}, \mathrm{Rh}$ and PAH contamination levels on a whole fodder plot scale.

\section{REFERENCES}

Bakker M.I., Trolls J., Kollöfel C. (2001a) Deposition of atmospheric semivolatile organic compounds to vegetation, Am. Chem. Soc. 16, 218-236.

Bakker M.I., Koerselman J.W., Tolls H., Kolloffel C. (2001b) Localization of deposited polycyclic aromatic hydrocarbons in leaves of plantago, Environ. Toxicol. Chem. 20, 1112-1116.

Barbante C., Veysseyre A., Ferrari C., Van de Velde K., Morel C., Capodaglio G., Cescon P., Scarponi G., Boutron C. (2001) Greenland snow evidence of large scale atmospheric contamination for platinum, palladium and rhodium, Environ. Sci. Technol. $35,835-839$.

Barefoot R.R. (1999) Distribution and speciation of platinum group elements in environmental matrices, Trends Anal. Chem. 18, 702-707.

Bryselbout C., Henner P., Carsignol J., Lichtfouse E. (2000) Polycyclic aromatic hydrocarbons in highway plants and soils, Evidence for a local distillation effect, Analusis 28, 32-35.

Bunger J., Stork J., Stalder K. (1996) Cyto and genotoxic effects of coordination complexes of platinum, palladium and rhodium in vitro, Int. Arch. Occ. Env. Hea. 69, 33-38.

Castelain P.Y., Castelain M. (1987) Contact-dermatitis to palladium, Contact Dermatitis 16, 46-46.

Colvile R.N., Hutchinson E.J., Mindell J.S., Warren R.F. (2001) The transport sector as a source of air pollution, Atmos. Environ 35, $1537-1565$.

Crépineau-Ducoulombier C., Rychen G., Feidt C., Le Roux Y., Lichtfouse E., Laurent F. (2003) Contamination of pastures by polycyclic aromatic hydrocarbons (PAHs) in the vicinity of a highway, J. Agr. Food Chem. 51, 4841-4845.

Crépineau-Ducoulombier C., Tankari Dan-Badjo A., Rychen G. (2004) PAH contamination of the grass Lolium perenne exposed to vehicular traffic, Agronomie 24, 503-506.

Crépineau-Ducoulombier C., Feidt C., Rychen G. (2005) Palladium and Platinum transfer to milk and organs of lactating goats, VI European Meeting on Environmental Chemistry, Belgrade, Serbia and Montenegro, December 6-10.

Djingova R., Kovacheva P., Wagner G., Markert B. (2003) Distribution of platinum group elements and other traffic related elements among different plants along some highways in Germany, Sci. Total Environ. 308, 235-246.

Dugay A., Herrenknecht C., Czok M., Guyon F., Pages N. (2002) New procedure for selective extraction of polycyclic aromatic hydrocarbons in plants for gas chromatographic - mass spectrometric analysis, J. Chromatogr. A 958, 1-7.

Duran A., de Lucas A., Carmona M., Ballesteros R. (2001) Simulation of atmospheric PAH emissions from diesel engines, Chemosphere 44, 921-924.

Ely J.C., Neal C.R, Kulpa C.F., Schneegurt M.A., Seidler J.A., Jain J.C. (2001) Implications of platinum-group element accumulation along US roads from catalytic-converter attrition, Environ. Sci. Technol. $35,3816-3822$.
Garrec J.P., Van Haluwyn C. (2002) Biosurveillance végétale de la qualité de l'air, Tec \& Doc, Paris.

Garrec, J.P., Renard E. (1996) Foliar absorption of aluminum: Study of the fixation and of the cuticular penetration, Environ. Exp. Bot. 36, $365-375$

Gebel T., Lantzsch H., Plesow K., Dunkelberg K. (1997) Genotoxicity of platinum and palladium compounds in human and bacterial cells, Mutat. Res. 389, 183-190.

Grova N., Laurent C., Feidt C., Rychen G. Laurent F., Lichtfouse E. (2000) Gas chromatography - mass spectrometry study of Polycyclic aromatic hydrocarbons in grass and milk from urban and rural farms, Eur. J. Mass. Spectrom. 6, 457-460.

Grova N., Rychen G., Monteau F., Le Bizec B., Feidt C. (2006) Effect of oral exposure to polycyclic aromatic hydrocarbons on goat's milk contamination, Agron. Sustain. Dev. 26, 195-199.

Hautala E.L., Rekilä R., Tarhanen J., Ruuskanen J. (1995) Deposition of motor vehicle emissions and winter maintenance along roadside assessed by snow analyses, Environ. Pollut. 87, 45-49.

Helmers E., Mergel N. (1998) Platinum and rhodium in the polluted environment: studying the emissions of automobile catalysts with emphasis on the application of CSV rhodium analysis, Fresenius J. Anal. Chem. 362, 522-528.

Kipopoulou A., Manoli E., Samara C. (1999) Bioconcentration of polycyclic aromatic hydrocarbons in vegetable grown in an industrial area, Environ. Pollut. 106, 369-380.

Klumpp A., Ansel W., Klumpp G., Belluzzo N., Calatayud V., Chaplin N., Garrec J.P., Gutsche H.J., Hayes M., Hentze H.W., Kambezidis H., Laurent O., Penuelas J., Rasmussen S., Ribas A., Ro-Poulsen H., Rossi S., Sanz M.J., Shang H., Sifakis N., Vergne P. (2002) EuroBionet: A Pan - European Biomonitoring Network for Urban Air Quality Assessment, Environ. Sci. Pollut. R. 9, 199-203.

Moldovan M., Gomez M.M., Palacios M.A. (1999) Determination of platinum, rhodium and palladium in car exhaust fumes, J. Anal. Atom. Spectrom 14, 1163-1169.

Moldovan M., Rauch S., Gómez M., Palacios M.A., Morrison G.M. (2001) Bioaccumulation of palladium, platinum and rhodium from urban particulates and sediments by the freshwater isopod Asellus aquaticus, Water Res. 35, 4175-4183.

Pallas J.E., Jones J.B. (1978) Platinum uptake by horticultural crops, Plant Soil 50, 207-212.

Rauch S., Morrison G.M., Moldovan M. (2002) Scanning laser ablationICP-MS tracking of platinum group elements in urban particles, Sci. Total Environ. 286, 243-251.

Schafer J., Hannker D., Eckhardt J.D., Stuben D. (1998) Uptake of trafficrelated heavy metals and platinum group elements (PGE) by plants, Sci. Total Environ. 215, 59-67.

Shabad L.M. (1980) Circulation of carcinogenic Polycyclic Aromatic Hydrocarbons in the human environment and cancer prevention, J. Natl. Cancer 64, 405-410.

Thomas G.O., Smith K.E.C., Sweetman A.J., Jones K.C. (1998) Further studies of the air - pasture transfer of polychlorinated biphenyls, Environ. Pollut. 102, 11-128.

Wild S.R., Jones K.C., Johnston A.E. (1992) The polynuclear aromatic hydrocarbon $(\mathrm{PAH})$ content of herbage from a long-term grassland experiment, Atmos.. Environ. 26a, 1299-1307. 